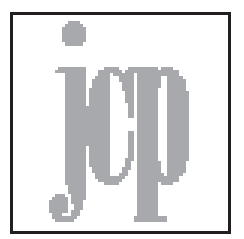

\title{
Persia and the Politics of Muslim Identity from Medieval to Early Modern Romance
}

\author{
Hafiz Abid Masood \\ Department of English | International Islamic University Islamabad \\ abid.masood@iiu.edu.pk
}

\section{ABSTRACT}

This article delineates a continuity between the medieval representation of antiChristian Persia in Crusade narratives and romances and the anti-Christian identity of Persia in early modern English romances from the 1580s. It links three major ways of perceiving Persia in England in the sixteenth and seventeenth centuries when the predominant identity of Persia was anti-Ottoman and thus pro-Christian. This was due to the rise of the Safavid dynasty under Shah Ismail in 1501 and the subsequent wars between the Turks and Persians throughout the sixteenth and seventeenth centuries. The second and equally important identity of Persia was classical. This had its origin in the Greek and Roman histories translated by the Renaissance humanists into English and other vernaculars. Cyrus, Darius and other Achaemenid Persian kings were well known in Renaissance England. The third set of ideas about Persia in early modern England conflated Safavid Persians and Ottoman Turks as a force united against Christendom. These three identities, in most cases, operated alone, but in some cases, two of these trajectories overlapped with each other. This article discusses the third trajectory of Persia that developed in the latter half of the sixteenth century in proto-crusading romance texts displaying strong medieval underpinnings. These proto-crusading romances include Munday's Zelauto, Johnson's Seven Champions of Christendom and Tasso's Gerusalem Liberata.

Keywords: Safavid Persia, anti-Christian identity, Ottomans and Safavids as allies 
The history of seeing the Persians as enemies of the West and Christianity has its roots in the European Middle Ages in the wake of the Crusades. Subsequently, Renaissance humanists discovered a strange resemblance between classical Persians and their contemporary Ottoman Turks, and both were seen as enemies of Western civilisation. This reading of classical Persians as forerunners of contemporary Ottomans was one of the ways to conflate the two under an overarching Muslim identity. It reveals how the early modern identity of Ottomans was transported to the Persian past and, consequently, how the Persians and Ottomans joined together on account of their aggression against the Greeks and early modern Europeans. This generated anxiety in early modern Europe which was compounded by the presence of the Ottoman threat in the east. In these circumstances, Catholics called for unity among Christians in order to defend themselves against the Ottoman threat and to further boost the anxiety that overlooked the division in the house of Islam. Thus, it was believed that given the Ottoman or larger Muslim threat to the Christians, it would be a great idea to exhort diverging Christians to come together.

In this regard, the most important source for the projection of this PersianIslamic anti-Christian identity was the medieval romances that presented Persia as an enemy of Christendom. This representation of Muslims in medieval literature has garnered a lot of attention over the last few decades. ${ }^{1}$ However, none of the works really looks into the representation of different ethnicities professing Islam in the medieval imagination. It is generally thought that 'Saracen' was the only term used to denote a Muslim during the Middle Ages. The term 'Saracen' was replaced by other ethnic terms such as Turk, Moor and Persian in the early modern period, though Saracen still had a residual presence in the same period. It has been argued by Suzanne Conklin Akbari in Idols in the East that the "... medieval construction [of Muslims] conflated categories of ethnicity and religion within a single term that served as a marker of both, that is 'Saracen'” (285). She goes on to state that in the early modern period, the term 'Saracens' was replaced with ethnic terms such as 'Turks' and 'Moors'. She believes that “...the predominance of terms that denote ethnic or racial alterity ('Turk' and 'Moor') in place of a term that had denoted both racial and religious alterity ('Saracen') signals a fundamental distinction between medieval and early modern Orientalism” (285). I argue that the practice of naming Muslims in the medieval period is more complex than this. 'Saracen' was one of the major terms for Muslims in medieval Europe but what follows will show that the medieval Europeans were also aware of different ethnicities among the 'Saracens'. At least, they knew that Persia was ruled by a sultan and the Persians followed the edicts of the Prophet Muhammad. So, in a sense, the term Persian, like Saracen, denoted ${ }^{1}$ On the representation of Islam in Medieval English Literature, see Melitzki, Dorothee, The Matter of Araby in Medieval England, New Haven: Yale University Press, 1977; Calkin, Siobhain Bly, Saracens and the Making of English Identity: The Auchinleck Manuscript, London and New York: Routledge, 2005. 
both ethnicity and religion in the medieval period.

The tradition of conflating Persians and Saracens or presenting them as allies goes back to Old English literature as has been shown by Katherine Scarfe Beckett. Citing evidence from the Pseudo-Methodius' Reuelationes 1 and Aelfric's Book of Judges, she shows that the Anglo-Saxon perception of Persia was "Saracenical" and anti-Christian as both accounts present Persia as an enemy of the Romans. (Beckett 155 \& 185) Presenting Persia as anti-Christian was given a new impetus in the wake of the crusading movement when the Persians allied with the Arabs to fight against the crusaders. Persian characters figure in medieval English and French romances and the Persian ruler is usually called the Sultan of Persia. One example of this trend is found in the Middle English Version of Partonope of Blois. This French romance was translated into English during the Middle Ages and, towards its end, the protagonist fights against the Sultan of Persia and kills him. The romance describes the "sawden of Perce" as the one who "[...] to Cristes lawe is adverse/ And levith on Mahound[...]" (1l.8750-51).

William Wistar Comfort, in his article on the Saracens in Italian poetry, also mentions Persia as a location where the hero of Chanson de Roland stays for some time, disguising himself as a Persian, solving disputes between Muslims, and almost falling in love with Diones, the daughter of the Persian ruler. Comfort specially mentions Diones' prayer to God in which she recognises both Jesus and Muhammad as prophets of God "[...] now seated respectively upon the right and left hand of God in glory" (885). The protagonist of another romance titled Orlando that was composed circa 1400 is said to have gone to Persia where he performed St George-like feats in the Persian court and eventually killing the Persian king, resulting in the conversion of two of his children (895). This means that the Saracens in medieval romances were not only Arabs, as is generally understood, but also Muslims of other ethnic identities, such as Persia, as can be seen in the above examples.

Persians and their ruler, the Sultan of Persia, also appear in other medieval romances. One scholar mentions the presence of Persians in the 12 th century Romance of Horn. The leader of the Saracens in this romance is called the "soudein 'Sultan of Persia' (2930, 3000)" (Speed 575). Another example of the Sultan of Persia is found in Guy of Warwick where the son of the Sultan and another player play a game of chess. ${ }^{2}$ Upon losing the game, the Persian prince and his rival player start fighting, and the Persian prince is killed by the other player. ${ }^{3}$ The Sultan of Persia also appears as an ally of the Sultan of Babylon in Sir Bevis of Hamptoun, while in Sir Otuel,

${ }^{2}$ The game of chess itself reveals the Persian connection as the game was known in Persia in the classical period.

${ }^{3}$ For details of the story, see Ellis, G. (Ed.) (1805) Specimens of Early English Metrical Romances Chiefly Written during the Early Part of the Fourteenth Century... London, Longman, Hurst, Rees, and Orme. pp. 61-62. 
a Christian knight is sent to kill the King of Persia, Perigon. We also find a reference to "Sowdan of Perce" in Sir Gowther. The Christian Emperor in the romance receives an emissary from the Sultan of Persia with the message that the Emperor should send his beautiful daughter to him so that he can marry her. When the emperor refuses to comply with the request, the Sultan's and the emperor's armies face each other on the battlefield. ${ }^{4}$ All these references reveal that medieval romance perceptions of Persia were strongly Islamic and anti-Christian, which diverges from the early and mid-sixteenth century English perception when the antagonism between Persia and the Ottoman Turks was thought to be serving the Christian cause.

This representation of Persia in early modern England as an ally of Christendom relied heavily on the idea that Christians and Persians could join forces against the Ottomans. Consequently, a sense of unity and proximity between the two started emerging in Europe. It was necessary for the success of such a project in order to undermine Persia's Islamic identity, and this was done by writers who were convinced of the viability of the idea. Recently, works dealing with images of Persia in early modern England have suggested how the representation of Persia was different from that of the Ottoman Turks. Anthony Parr contrasts the two sets of representations in his introduction to Three Renaissance Travel Plays. He elaborates how the Europeans saw the Ottoman Empire as "a deeply alien culture" and the hatred of Islam coupled with the perception of the cruelty of the Ottoman Sultan resulted in "an immovable stereotype of the raging and expansionist Turk". However, he adds, "Persia was a rather different case ... Like India or Japan, it was not so much Europe's Other as its opposite or foi" (Parr 11). This is an interesting position, suggesting that early modern Europeans defined and fashioned themselves in opposition to the Ottoman Turks while the Persians were seen as a pale reflection of the Europeans themselves, thereby demonstrating the possibility of a 'Perso-Christian alliance'. This possible alliance hinged on the idea of the Persians' presumed affinity with Christianity that has been trumpeted by early modern authors.

However, there was a deflection in subsequent writings which presented Persia as an enemy of Christianity and the difference between Ottomans and Persians is obliterated. They both share the same ground as far as their opposition to Christianity is concerned. The Sultan of Persia, as the Persian ruler is called in such texts, is transformed into the Ottoman Sultan, Persian soldiers become the Janissaries and Turk and Persian become synonymous. The employment of the term sultan for the Persian king, as opposed to sophy that is used in proto-Christian representations of Persia, is in itself instructive. Sophy was a term that placed the Persian king squarely in the Christian imagination because of the familiarity of the term. It would

${ }^{4}$ For further details, see 'Sir Gowther' (ll.373-432) in Rumble, T. C. (Ed.) (1965) The Breton Lays in Middle English, Detroit, Wayne State University Press. 
have reminded early modern readers and auditors of the Greek Sophists, Saint Sophy or Hagia Sophia. This, however, does not mean that the term sophy was exclusively used in texts that present Persia as proto-Christian. It is also used in texts that present Persia in Islamic hues, as in Anthony Munday's Zelauto.

\section{Munday's Persia as a Locus of Christian Persecution}

Zelauto, by Munday, narrates the story of the adventures of the eponymous protagonist in diverse parts of the world and one section of the story is set in a Persian city called Zebaia. The major theme of this section is the significance of showing courtesy to strangers, but in the course of the narration, Munday attempts to show the plight of the Christian minority living in that Persian city and how Zelauto rescues one Christian convert from being burnt at the stake. There are a few woodcuts in the text as well and one of them shows a Christian woman bound to the stake while the Sultan of Zebaia looks on passively. While analysing this scene, Benedict Robinson asserts that in telling the story of the persecution of a Christian at the hands of a Muslim sultan in Persia, Munday, in fact, critiques the religious violence that was so rampant in contemporary Europe as a result of the Catholic-Protestant divide, thereby recognising "something 'Persian' in the operation of religious violence in England” (33). Robinson compares this scene in the woodcut with Titian's 1543 painting of the crucifixion of Jesus Christ, which quite anachronistically incorporates the figure of Ottoman Sultan Suleiman (31). Taking my cue from this, I argue that the representation of the Sultan of Persia in Zelauto as a perpetrator of violence against Christians dissolves all the boundaries that separate the Turks and the Persians, and Persia emerges as a powerful "Other" to Christian Europe, like unto the Turks.

This representation of a sultan in Persia as a persecutor of Christians has some important points. Primarily, we observe a paradigm shift that is taking place here in which a sultan in Persia, and not an Ottoman sultan, is presented as an enemy of Christians despite the fact that the Ottoman persecution of Christians was more meticulously documented in early modern Europe than any persecution of Christians in Persia. This raises many questions. Did Munday intentionally omit the Ottoman Turks from his text because of the establishment of official diplomatic relations between England and the Ottoman Porte in the 1580s? What were the possible sources of Munday for such an image of Persia? One possible inference could be that he drew on continental sources as he had been in Rome a few years before the publication of Zelauto and this perception is reinforced by the fact that his hero is an Italian prince.

Another point worthy of note, emanating from Zelauto, is the presence of a secret Christian community in Zebaia. The fact that Christians had to hide their beliefs confirms the state of fear under which the Christian minority had to live in 
that part of Persia. The treatment meted out to Christians is made obvious when Zelauto enters an inn and to his astonishment finds a Florentine woman is his host. She informs him that "we are héere subiect vnder a Law, to which Law, wyll we, nyll we, we must obey, the Law dooth thus farre stretch in charge, that no Christian must abide in ye Cittie abooue ten days" (Munday 62). The law makes it abundantly clear that Christians are not welcome in that Persian city and those who live there have to suffer the cruelty of the Muslim rulers. The woodcut featuring the punishment of the woman, who is a close relative of the "Soldane", on account of her conversion to Christianity further reinforces the intolerance of Persians towards Christians and, as a consequence, the Persians are equated with the Ottomans.

The equating or mingling of Turk and Persian is evident in a few other places in Munday's text. At one point in the text we find the hero engaged in a dialogue with another character named Astraepho. Zelauto informs him that he left for Persia from England on a ship. And then to arouse the curiosity of his listener, he adds the following sentence, "But many were the myseries that I poore soule abode among the tyrannous Turkes" (52). Straepho's response to the above statement is also significant: "But durst you séeme to wander so farre as to put your selfe, in hazard of lyfe among those cruell and bloody Turkes" (52). The use of 'cruell' 'bloody' and 'tyrannou' 'Turkes' who live in Persia shows that Persia is clearly associated with Islam, and Munday is not following the line of his contemporaries who were tactical in undermining or silencing the Muslim identity of Persia, thus presenting it in a favourable light. There are a couple of references to Constantinople in Zelauto but Munday has nothing to say about its inhabitants. This further consolidates the perception that Persians and 'Turkes' were interchangeable terms for Munday. The title statement of the section is also instructive in this regard: "Zelauto. His Ariuall in Persia, his valiant aduenturing in the defence of a Lady, condempned for her Christianitie, his prosperous Perigrination among the tyrannous Turkes, with the rest of his Knightly deedes" (57). The 'tyrannous Turkes' of the title are none other than the Persians and here the epithet 'Turke' is employed by Munday in a religious sense and does not mean 'Ottoman' as it often does in the early modern context. Thus, there were many different types of Turks who were all Muslims. The three main varieties of 'Turks' in early modern texts were 'Persian Turks,' 'Turk Turks' and 'Moor Turks'. In such a usage of the word Turk, Persian, Turk and Moor become ethnic denominators of people who adhered to the same faith, i.e. Islam. The Turk Persians or Persian Turks in Munday's text are Muslims who inhabit Persia and they are different from the Ottomans in terms of their geographical location. Otherwise, there is no difference between the two. It is a point worth noting here that Munday's work predates the publication of reports from the Muscovy company agents who travelled to Persia in the 1560s and '70s, as well as John Thomas Minadoi's History of the Warres between the 
Turkes and the Persians which was printed in London in 1595.

The spectre of the unity of Muslims played an important political role in early modern England, and Europe at large, to shame the divided Christians. Though a strong sense of difference between the Turks and Persians had already existed in Europe with the emergence of the Safavid Empire in Persia, we find a number of texts ignoring this fact. As a result, Persia as an Islamic empire achieves an identity of its own and does not need to be defined in relation to the Ottomans. Thus, in the case of classical Persia and contemporary Persia, imbued with a strong Islamic identity, there is no need for Persia to be defined as involving antagonism to the Ottoman Turks. The Persia of the Sophy kings, on the other hand, is almost always defined differently to the Ottomans so that Persia and Europe became a common enemy for the Ottomans, and vice versa. However, Persia with a non-specific Islamic identity becomes Europe's enemy just like the Turks, and for this reason we need to consider Persia as a strong 'Other' for Christian Europe.

Munday's text rehearses a story common in medieval romances. The bravery and gallantry of the Christian knights against the Saracen hordes is one of the stock themes of romances. Zelauto also performs great deeds of courage in Persia to rescue Mica's sister from punishment as a result of his successful duel with the son of the "Soldane". Zelauto delivers a speech in front of the Soldane and his Lords and beseeches him to spare the life of the woman. He tries to embarrass the audience there by suggesting to the women present that if no man was ready to protect the innocent woman, one of them should come forward and try to save her. He offers three choices to the Soldane: first, to forgive her; secondly, if his extreme laws don't permit him the first choice, then he should exile her to another country; and thirdly, if neither is acceptable to him, then he says: "Héere am I by force of Armes to defend her quarrell, and against this your Champion will liue and dye in her defence" (84). Zelauto is left with no choice but to fight against Terolfo, the Soldane's son.

The fight was "valiant" and "excellently well-handled on bothe sides", which shows that Munday wants his readers to acknowledge the military skills of the Persian prince as well. This is in line with the medieval concept of romance, presenting the enemy as the "virtuous pagan", and difference of religion did not require the writer to deprive the enemy of their skills. ${ }^{5}$ The Soldane, after the death of his son at the hands of Zelauto, spares the woman who was to be punished but imprisons Zelauto on account of his son's death. Zelauto is later secretly helped by the Christians in Zebaia, succeeds in escaping from Persia safely and crosses the border to go to Constantinople. The conclusion of the story shows that Munday chose Persia very carefully as a site for describing the plight of Christians. Ottoman Constantinople is ${ }^{5}$ On this point see Vitto, C. L. (1989) The Virtuous Pagan in Middle English Literature, Philadelphia, The American Philosophical Society. For a more recent assessment of the same issue see Grady, F. (2005) Representing Righteous Heathens in Late Medieval England, New York, Plagrave Macmillan. 
shown as a safe haven for Zelauto as compared to the Persian city of Zebaia. Munday's representation of Persia runs counter to the images promulgated by a number of other early modern authors who were at pains to demonstrate the Persians' difference from the Ottomans, especially in their treatment of Christians.

\section{St George: A Christian 'Champion' in Persia}

An important point to note is that Munday, while writing in the medieval romance tradition, uses the term "Champion" for Zelauto. It seems that all the works that represent Persia as an Islamic power employ the quintessentially romance terminology of 'Champions'. One prominent example of this trend is found in Richard Johnson's Seven Champions of Christendom. The full title of the prose fiction explains who the seven champions were and what they did:

The most famous history of the seauen champions of Christendome Saint George of England, Saint Dennis of Fraunce, Saint Iames of Spaine, Saint Anthonie of Italie, Saint Andrew of Scotland, Saint Pattricke of Ireland, and Saint Dauid of Wales. Shewing their honorable battailes by sea and land: their tilts, iousts, and turnaments for ladies: their combats vvith giants, monsters, and dragons: their aduentures in forraine nations; their inchauntments in the holie land: their knighthoods, prowesse, and chiualrie, in Europe, Affrica, and Asia, with their victories against the enemies of Christ (Munday). The title shows that the work contains all the building blocks that are necessary for a romance: jousts and tournaments for women, fights with monsters and dragons, adventures in far-off lands, prowess and chivalry and, most importantly, "their victories against the enemies of Christ". This also reveals how much early modern writing was influenced by medieval romance. In the assessment of David Salter, "Nowhere is the influence of medieval romance on Elizabethan literature more apparent than in Richard Johnson's enormously popular prose tale” (Salter 6). The same view is held by David Margolies who considers Richard Johnson "the most enduringly successful of the commercial writers" because "his Seven Champions of Christendom was still current as a children's book in the nineteenth century" (Margolies 35). But despite this popularity and the commercial success of The Seven Champions, we find very little attention paid to this work in recent scholarship. Salter attributes this lack of attention to assessment of the work as devoid of any literary merit, which Salter seems to share (6). Naomi Conn Liebler in her recent essay on The Seven Champions considers the non-availability of the text in a modern spelling edition as one cause of a lack of attention. When Richard Johnson gets any attention from modern scholars, "he is - at best - damned with faint praise" (Liebler 114). Both Salter and Liebler, after showing modern scholarship's disregard for The Seven Champions, nevertheless assert the significance of the text in understanding early modern attitudes towards early modern book and reception history. 
The central place assigned to St George among the seven champions clearly shows his increasing iconic value in early modern England. He has naturalized him as the son of an unnamed English king and a resident of Coventry. In this regard, Jerry Brotton highlights the 'contested' image of St George in the early modern period that was, on the one hand, appropriated by both Catholics and Protestants against each other, and on the other was thought to be a link between the East and the West. Yet another way St George was perceived in early modern texts and iconography was his role as a Christian knight against Muslims. The dragon he fights comes to represent Islam in some early modern accounts of St George (Brotton 60). This antiIslamic identity of St George gets fuller expression in Richard Johnson's The Seven Champions where, according to Brotton, he "is redefined as the iconoclastic Protestant martyr destroying the fictional symbols of Islamic idolatry" (60). What Brotton does not underscore is that St George's iconoclasm is directed against the Persians, which reveals the emergence of a new Persian identity in an early modern text.

St George, as an important figure, appears in both Spenser's The Faerie Queene and Shakespeare's history plays. Because of the presence of St George as the Red Cross Knight in The Faerie Queene, Liebler calls The Seven Champions a “working-man's Faerie Queene, minus the allegory and the poetry" (114). The major portion of the first part of Seven Champions is devoted to the feats of St George and the three sites chosen by Johnson to exhibit the Christian Champion's valiant deeds are Egypt, Persia and Morocco. Curiously enough, like Anthony Munday's Zelauto, the Ottomans are not the main enemy that St George must encounter. Apart from a few references to "Turkish fashion", "Turkish bowes and Darts" and a "Turkish blade", there is only one reference to "Turkish" soldiers, thus attributing very little value to the Ottoman enemy. On the other hand, pitting Persia against the patron saint of England, i.e. St George, transforms Persia into an enemy of England par excellence.

Egypt is the first destination of St George on his eastern travels. The country is shown plagued by a dragon that has terrified the lives of the Egyptians. The Egyptian king had declared that whosoever was courageous enough to combat the dragon and get rid of it would deserve to marry his daughter. St George kills the dragon and is hopeful of winning the hand of the Egyptian king's daughter. But his hopes are shattered when he knows that a Moorish king, Almidor, then residing in the Egyptian king's court, craves the love of the Egyptian king's daughter, Sabra. Though, at first, St George is well entertained in the Egyptian court and Sabra falls in love with him, Almidor eventually succeeds in changing the mind of the Egyptian king about St George on account of St George's successful attempt to convert Sabra. Sabra'sand as a consequence Egypt's - Islamic identity is firmly established when George persuades her to convert to Christianity because he declares himself a Christian, and her "a Pagan", so she must forsake her religion in order to be with him (Johnson 22). 
Sabra readily agrees to his proposal, saying: "With al my soule (answered the Egiptian Lady) will I forsake my country Gods, \& for thy loue become a Christian" (22). The conversion of Saracens entangled in love with Christians is a common motif in medieval romance. ${ }^{6}$ This influence is also apparent throughout the text and especially in the oaths of Muslim rulers. When the Egyptian king is informed by Almidore of the conversion of his daughter, he is infuriated and bursting with anger, invoking " $\mathrm{Ma}$ homet, Apollo, and Termagaunt, thrée Gods we Egiptians commonly adore" as he vows to punish St George (22-23). The purpose of this representation was to represent Muslims as idolaters and easily distinguishable from Christianity.

The three gods ascribed to the Egyptian king found their way into Johnson's narrative via medieval romances and the purpose of this was to represent Muslims as idolaters and easily distinguishable from Christianity. Once Ptolomie, the Egyptian king, turns against St George, he decides to send him to the Sultan of Persia, whom he refers to as his "cosen". He writes a letter to the Sultan explaining to him the dangers of St George and requesting he be put to death as soon as George reaches Persia. The King of Egypt's reason for putting George to death given in the letter gives the same identity to Persia and Egypt in religious terms. St George, according to the Egyptian king, "is an vtter enemie to all Asia and Affrica, and a proude contemner of our Religion" (23). The religion of the Persian sultan and the Egyptian king are further tied together through the agency of the three gods that are common to both Egyptians and Persians. Johnson narrates how St George, upon reaching Persia, witnessed their religious rituals of sacrifice "to their Gods Mahomet, Apollo, Tirmigaunt". This "vnchristian Procession", as Johnson characterizes it, was so reviled by St George that he could not control himself, attacked the procession and trampled the Persian Gods under his feet. Seeing this, the Persians, who are called pagans rather than Mahometans, rush to their sultan for help and inform him how St George had "despised their Mahomet and trampled their banners in dust" (25). The references to Mahomet here and in subsequent chapters of the Seven Champions conjure up an image of Persia that is endowed with a solid idolatrous Muslim identity. This Muslim identity of Persia emerges in opposition to St George, who was the patron saint of England and a national icon. This firmly establishes Persia as an enemy of England as well as Christendom in the English imagination. Furthermore, this blurring of boundaries between Turks and Persians is the hallmark of this new identity of Persia that is anti-Christian, anti-Europe and anti-English, as opposed to the anti-Ottoman and anti-Sunni position given to them by so many observers of Perso-Ottoman affairs during the early modern period.

\footnotetext{
${ }^{6}$ On the idea of conversion and love in Middle English romances, see Ewoldt, Amanda M., "Conversion and Crusade: The Image of the Saracens in Middle English Romance," Unpublished PhD Dissertation, University of Louisiana Lafayette, 2018. Also see Melitziki, Chapter 6, section titled "The Marriage Theme as a Portrayal of Christian-Muslim Relations" pp. 136-160.
} 
The process of creating this new anti-Christian identity for Persia continues in the events next described by Johnson. He narrates how St George encounters 100 Persian knights sent by the sultan to arrest him. The Persians, who are called the enemies of Christ, were all murdered by St George and there were piles of their dead bodies all around bathed in their blood. He is finally presented before the Persian sultan who pledges to punish him according to the wishes of the Egyptian king, who takes an oath on Mahomet, Apollo and Termagaunt to show his commitment to the action. The Persian soldiers are called 'Persian knights' at some points in the narrative, but more interestingly, they are also called 'janissaries'. Janissaries constituted an important military order in the Ottoman army while among the Persians there was no such cadre as the Janissaries. By mingling Persia and the Ottoman military order, the author is trying to convey the idea that there is really not much difference between Turks and Persians, and as the Ottomans were the enemies of Christendom, so were the Persians. Alternatively, it is also possible that he considered all Asian 'knights' to be 'janisarries'.

\section{"Sultan of Persia" and its Medieval Antecedents}

The title Sultan of Persia, like the Islamic Persian identity, clearly derives from medieval literature such as crusade chronicles and popular romances. The chronicles of the first crusade mention a Sultan of Persia whom the Saracen ruler of Antioch wrote to for help when the city was besieged by the Crusaders. The Seljuk Turks ruled Persia at the time of the first crusade and this association between Persia and Turks might have lingered on in the minds of these early modern writers who clearly modelled their texts on medieval romances that emerged in Europe as a result of the early Crusades. This association of Persians and Turks is clearly visible in the first crusade's Chronicle of Fulcher of Charters where the chronicler is narrating the events just before laying the siege of Nicea:

We hastened then to the city of Nicea, which Lord Bohemond, Duke Godfrey, Count Raymond, and the Count of Flanders had already surrounded in siege by the Middle of May. The OrientalTurks, very keen archers and bowers, then possessed this city. These Turks from Persia, after they had crossed the Euphrates River fifty years before, subjugated the whole land of Romania for themselves as far as the city of Nicomedia. (Peters 63)

“These Turks from Persia" clearly shows that in the Middle Ages, Turks and Persians were two ethnic terms unlike in the early modern period, when Turks and Persians came to signify both an ethnic identity and a sectarian identity, as Sunni and Shi'a, respectively. The same chronicler also mentions the help received by the ruler of Antioch from the "Sultan of Persia" when the former was besieged by the Crusaders: When the Turks saw that they were besieged by such a great Christian multitude, they feared that they could in no way shake them off. After a plan was 
mutually formed, Aoxian, prince and emir of Antioch, sent his son, Sensadolus ${ }^{7}$ by name, to the Sultan, that is, the emperor of Persia, to get his help most quickly, since they held hope for aid from no other except Mohammed, their advocate. (Peters 71-72)

Carol Sweetenham and Linda Paterson, in their study of Canso d'Antiocha, an Occitan epic relating the story of the First Crusade, have referred to the role of Sultan of Persia in the First Crusade. Discussing the First Crusade texts translated into Spanish in the late thirteenth century under the title Gran Conquista de Ultramar (GCU), the authors inform us that GCU abridges its sources. For example, "II, 68," describes how the Sultan of Persia sends out letters to all corners of the Saracen world; this appears in much more detail in the Antioch (Sweetenham 30). The authors also mention the request from the governor of Antioch, who is named as Yaghi-Sian in Antioche, to the Sultan of Persia for aid (82). Another important reference to the Sultan of Persia is found in this text and it relates to a geographical location in Persia called Khurasan, where the sultan had his main court, "In the Antioche $(4790,5080)$; for example, it appears to refer to the headquarters of the Sultan of Persia" (Sweetenham 336). ${ }^{8}$ This evidence is enough to show that the European texts dealing with the First Crusade loudly pronounced a Persian Islamic identity and their animosity against the Christians. ${ }^{9}$

It should not be assumed that sultan was the only title used for the Persian ruler in medieval romances. We have noted one example of the usage of king for the Persian ruler above and it was also a common title for the ancient Persian kings, such ${ }^{7}$ According to Carol Sweetenham, in her edition of Robert the Monk's History of the First Crusade says that Sensadolus is the Western rendition of Shams-ed-Daula. See note 18 on page 152 in Sweetenham, C. (Ed.) (2005) Robert the Monk's History of the First Crusade, Aldershot, Ashgate.

${ }^{8}$ For more details on this see Murray, A.V. (1995) "Coroscane: Homeland of the Saracens in Chanson de Geste and the Historiography of the Crusades". In Hvan Dijik, W. N. (Ed.) Aspects de l' e'pope'e romance. Mentalities, Ideologies, Intertextualities. Amsterdam, Groningen.

${ }^{9}$ The Sultan of Persia can also be spotted in German medieval romances as has been shown by Albrecht Classen in one of his articles. Two of the romances that feature Persian characters are the anonymous late thirteenth century Reinfried von Braunschweig and Konrad von Wurzburg's Partonopier und Meliur. The first romance deals with a Persian king who invites his victorious rival to visit his country and stay there to enjoy the luxuries there while the second one involves the competition between a "soldan" of Persia and the Christian hero, Partonopier to win the love of the same lady, Meliur. According to Classen, "In terms of character, chivalry, social status, political reputation, and personality, Partonopier and the Persian king (soldan) prove to be equals, and the narrative indicates that Meliur's choice for the Persian king might have been a very likely possibility if not for the true love between her and Partonopier" [I think this is an important point that might potentially be obscured if we focus too strongly on the Sultan of Persia's enmity towards Christianity - i.e. it may be worth emphasizing (again) that despite the Sultan's 'pagan' beliefs and hostility to Christianity, he is nevertheless perceived as an equal and wor thy adversary, and not some monstrous and culturally alien 'Other'] Classen, A. (2005) “Die Heidin: A Late-Medieval Experiment in Cultural Rapprochement between Christians and Saracens”. Medieval Encounters, 11, 50-70. 
as Cyrus and Darius, when they are mentioned in medieval narratives. Another title for the Persian ruler used in Huon of Bardeaux is 'Admirall'. Part of the romance deals in detail with the adventures of Huon in Persia and Media. Huon stays in Tauris in Persia and the Admiral of Tauris is described as the ruler of Persia. The admiral is presented as a Muslim who is persuaded by Huon to convert to Christianity. The conversion of the admiral is facilitated by the narration of the miraculous escape of Huon from the 'Goulfe of Perse' which showed that Huon's religion is true. The admiral who is already impressed by Huon's story is further enticed by the promise made to him that if he agrees to convert, he will give him an apple which when consumed will transform him into a young man 30 years old. To this the admiral responded:

[...] yf it be so... what so euer come of me I wyll be chrystenyd and byleue in ye law of Iesu chryst, the fere of dethe shall not let me to do it, for to longe I have byleuyd in this false lawe and detestable of Macomet[...]. (Lee 461-62)

After his conversion, the admiral along with Huon succeeds in converting the other lords of Persia to Christianity and they all march towards Angorie to fight against the Saracens.

The significance of the discourse pertaining to a Persian Muslim identity can be seen in the superimposition of the Muslim identity on classical Persia. This trend is evident in the medieval romances and histories of Alexander the Great and his conquest in the Orient. Suzanne Conklin Akbari points to the conflation of classical Persians and medieval Saracens in Liber Floridus by Lambert of St Omer and Roman de Toute Chevalrie by Thomas of Kent. In Liber Floridus, the author forges a connection between the defeats of Darius' army at the hands of Alexander's forces with the Frankish victory over the Saracens and the latter's entry into Jerusalem. This conflation is even more apparent in Roman de Toute Chevalrie. According to Akbari:

This typology is even more pronounced in the Roman de tout Chevalerie, where Darius' Persians are explicitly identified as "Sarazins" who adore "Apolin" and "Tervagant" two of the three most popular deities in the medieval Saracen pantheon. $(110)^{10}$

This is the reason why John Gower called Darius a "soldanus percie" in Confessio Amantis. (Clxiij). This anachronistic projection of Persian Muslim identity onto classical Persia was a consequence of the prevalence of references to the Sultan of Persia in medieval narratives.

\section{Tasso's Gerusalemme Liberata and Anti-Christian Persian Identity}

The Islamic anti-Christian identity of Persia re-emerges in some other early modern texts that tapped into medieval texts or narratives as source material. Torquato Tasso's Gerusalemme Liberata, a Crusade text as the title suggests, is an early modern ${ }^{10}$ More details on this can be found in Reiner, E. L. (2008) "The Ambiguous Greek in Old French and Middle English Literature”. Centre for Medieval Studies. University of Toronto. Specially see pp 122-161. 
text that paints Persia in the medieval romance model as anti-Christian and an ally of other Muslim forces of Turks, Moors, Indians, Arabs and Tartars. Tasso's poem was immensely influential in Elizabethan England. The poem was published in Italy in 1581 and it has been suggested by C. P. Brand that Liberata influenced the modelling of Spenser's Faerie Queene, which shows that it was known in England in the original Italian. ${ }^{11}$ The popularity of Tasso can also be gauged from the fact that three successive English monarchs. from Elizabeth to Charles I, had shown an interest in Liberata. Brand mentions that Queen Elizabeth I learnt passages of the poem by heart (Brand 226) while James I and Prince Charles were instrumental in the publication of the second edition of Edward Fairfax's translation of Gerusalemme Liberata in 1624, and this reprint was dedicated to Prince Charles (Kathleen 35). Edward Fairfax's complete translation of Liberata was published in 1600 and has been reprinted a number of times since then. ${ }^{12}$ There were other renderings of the poem in the course of the eighteenth and nineteenth centuries which all hint at the popularity of the poem in England. However, despite the popularity of Tasso's poem in early modern England, recent studies on Anglo-Islamic relations have not paid much attention to the representation of Islam in Tasso. ${ }^{13}$ Nabil Matar and Daniel Vitkus underscore the significance of the poem in the context of early modern discourse on Muslims. Matar calls Tasso's epic "the most influential Renaissance poem about the Crusades" (143) and contextualizes its appearance in England in terms of the late Elizabethan appeals for a crusade against the Muslims. On the other hand, Daniel Vitkus elucidates the comparative features of Tamburlaine and Tasso's Liberata but does not take into account the figure of Altamor in Tasso's poem who represents the historical Timur and Marlowe's Tamburlaine. Tasso's Altamor is diametrically opposed to Marlowe's Tamburlaine and reveals how multiple discourses about oriental figures were operating in early modern Europe.

Tasso's Gerusalemme Liberata is a counter-Reformation text. The fissure and rupture that developed in early modern Europe as a result of the Reformation was a great source of anxiety for early modern Christians. This anxiety was compounded by the presence of the Ottoman threat in the east, and in these circumstances Catholics called for unity among Christians in order to defend against the Ottoman threat and to further boost the anxiety that overlooked the division in the house of Islam. Thus, given the Ottoman or larger Muslim threat to Christians, it would be a

\footnotetext{
${ }^{11}$ For a comprehensive account of Tasso's influence in England see Brand, C. P. (1965) Torquato Tasso: A Study of the Poet and of His Contribution to English Literature, Cambridge, Cambridge University Press. On Tasso's influence on Spenser, see 228-38 of the same work.

${ }^{12}$ According to Brand, seven editions preceded the 1962 edition that was newly introduced by Roberto Weiss and published by Centaur Press in 1962.

${ }^{13}$ One essay that partially deals with the portrayal of Muslims in Tasso before the recent surge in studies on Anglo-Islamic relations is Donnelly, J. P. (1977) "The Moslem Enemy in the Renaissance Epic: Ariosto, Tasso, and Camoens”. Yale Italian Studies, 1, 162-170.
} 
great idea to exhort diverging Christians to come together. Since, at the same time, knowledge of the rupture among Muslims into Sunni and Shi' a became available and was also exploited by both Catholics and Protestants, Tasso seems to suppress any such reference to dissension among Muslims in his poem as it would have reflected a weaker Muslim enemy.

The Muslim enemy of the crusaders in Tasso's poem consists of various nationalities and ethnicities. They are Arabs, Africans, Turks and Persians and they come from all parts of the early modern Muslim world. Joining Persians with other Muslims is evidence of continuity between medieval and early modern perceptions of Persia where Islam becomes the most important norm defining a Persian identity. Consequently, all differences between Persia and Ottoman Turkey collapse and their identities become indistinguishable. The first mention of Persia in the poem is found quite early when Tasso relates the crusaders' victories in Nicea and Antioch:

Nice by assault, and Antioch by surprise,

Both faire, both rich, both wonne, both conquer'd stand, And this defended they in noblest wize

Gainst Persian knights and many a valiant band. $(I, 6)^{14}$

The Christian victory over "Persian knights" in Antioch is mentioned in Canto VIII and the Persian leader here is referred to as "Corbana". A Christian knight, Astragor, marvels at "How Anticoh was wonne ... And how defended nobly afterward" (VIII. 8). In the next stanza, Tasso explains whom Antioch was defended from:

Defended gainst Corbana valiant knight,

That all the Persian armies had to guide,

And brought so many soldiers bold to fight,

That void of men he left that kingdome wide. (VIII. 9)

Corbana or Corban, who is killed by Dudon in III. 44, is mentioned in narratives of the first Crusade. For example, in a letter by Anslem of Ribemont written to Manassess, Archbishop of Reims in July 1098, he is called "chief of the army of the king of Persians" (Krey 160). The defeat of the Persian military commander also inspired an engraving by Gregorio Pagani which appeared in a book published in Florence in 1589. ${ }^{15}$ The difference between Pagani's engraving and Tasso's description of the Persians' defeat is that whereas Corbana is killed by a minor lord in Tasso's poem, in the engraving, it is the greatest protagonist of the first crusade, Godfrey, himself who puts him to death. These texts were enough to remind their consumers of the role Persia played against the Christians in the past and this could have influenced early modern perceptions of contemporary Persia.

What is significant in Tasso's references to Persia is that, unlike the medieval ${ }^{14}$ I use Edward Fairfax's translation from Kathleen M Lea, T. M. Gang. (Eds.) (1981) Godfrey of Bulloigne: The Fairfax Translation of Tasso's Gerusalemme Liberata, Oxford, Clarendon Press.

${ }^{15}$ Gualterotti, R. (1589) Della descrizione del regale apparato fatto nella nobile citta di Firenze per la venuta, e per le nozze della serenissima madama Christina di Loreno moglie del serenissimo don Ferdinando Medici terzo gran duca di Toscana, Florence, Antonio Padovani, p.88. 
narratives of the First Crusade, there is no Sultan of Persia in the poem. Sultan, on the other hand, is used for the Turk ruler of Nicea, whose name is transcribed as Solimano and conflated with Soldano throughout the poem. In stanza 46 of Canto I we find another reference to a Christian-Persian encounter in which the Christians emerged victorious as their "swordes with Persian blood were dide" (I. 46). This leaves no doubt about the enmity of Christians and Persians.

Tasso does not only present Persians as the enemy of Christians, on a number of occasions, he conflates Turks, Persians as well as other Muslims to create an image of a joint force. One such occasion is in the speech of Alete, an Egyptian emissary to Godfrey in the company of Aragantes. Alete asks Godfrey:

Tell me, if great in counsell, armes and gold,

The Prince of Egypt, war gainst you prepare?

What if the valiant Turkes and Persians bold,

Vnite their forces with Cassanoes haire?

O then, what marble pillar shall vphold

The falling trophies of your conquests faire? (II. 71)

Egyptians, Persians, Turkes and Cassanoes' son are declared the four major enemies of the crusaders. Though Egyptians, Turks and Persians play an important role in defending Jerusalem against the Christians, the references to "Cassanoes haire" is the only reference to this character in the whole text. Though it is difficult to ascertain what historical figure Tasso meant with this, it may refer to Usumcasan of Marlowe's Tamburlaine who was an ally of the protagonist in the two-part play. If Cassanoe in "Cassanoes haire" is the Persian King Uzun Hasan, it also reminds us of a reference to “Tonombey, Usancassno's son” (Scene 27, 1. 26) in Greene's Selimus. ${ }^{16}$ It does show how Tasso and Greene might have read the same books about the Muslim Orient. The Egyptian ambassador, Alete, once again points to the possibility of an anti-Christian alliance between Turks and Persians on the one hand, and Egyptians on the other, which is the inverse of the strategy worked on by Christians against the Ottomans in the early sixteenth century and later revived by the Sherley brothers.

Islam was not only a military threat for Tasso's crusaders but also a sexual one. The Crusaders had to defend themselves against Muslim soldiers but also had to protect themselves from Muslim seductresses. Three important female characters in the poem are shown to be Muslims, i.e. Armida, Clorinda and Erminia. Armida is said to be the niece of the ruler of Damascus, while Erminia is the daughter of the ousted king of Antioch; Clorinda's origin is a slightly difficult issue. In his recent translation of the poem, Max Wickett describes her in the Glossary as a "Muslim maiden warrior, white-skinned daughter of the king of Ethiopia..." (Tasso 441). The first reference to Clorinda in the poem calls her "A Pagan damsel ... her visage faire"

\footnotetext{
${ }^{16}$ The reference is from Vitkus, D. (Ed.) (2000) Three Turk Plays from Early Modern England, New York, Columbia University Press.
} 
(I. 47), while in the next Canto, we get more information about her:

This lustie Ladie came from Persia late,

She with the Christians had encountered eft,

And in their flesh had opened many a gate

By which their faithfull soules their bodies left. (II. 41)

There is no explanation in the poem regarding why she comes from Persia. There is a probability that Tasso bestows on her a dual identity, although her being "whiteskinned" and Persian is more probable than her being a "white-skinned daughter of the king of Ethiopia”. Regardless of her ethnicity, Clorinda's arrival from Persia and her encounters with the Christians, in which she killed a lot of them, reinforces Persia's anti-Christian image.

The most significant episode involving Persia in the poem is in the last canto of the poem. This episode makes Tasso's poem radically different from other narratives that present the Persians as anti-Christian. Munday's Zealuto and Johnson's The Seven Champions of Christendom present an image of Persia which is entrenched in the past and is difficult to relate to the contemporary situation. Instead, Tasso's account turns classical, medieval and Safavid Persia into an anti-Christian Persia. This is evident in the final showdown between the crusaders and Muslims which starts with the blowing of trumpets. The first Muslim casualty is the "king of Orms, Hircano" (XX. 32) at the hands of the female crusader Gildippes. Next, she kills two other Persians named "Zopire" and "Alarcos" (XX. 33). The climax arrives in the next stanza:

A blow feld Artaxerxes, with a thrust

Was Argeus slaine, the first lay in a trance,

Ismaels left hand cut off fell in the dust;

For on his wrest her sword fell down by chance:

The hand let go the bridle where it lust,

The blow vpon the coursers eares did glance,

Who felt the raines at large, and with the stroake

Half mad, the ranks disordered, troubled, broake. (XX. 34)

In this extract, the most important word from our perspective is the deployment of the proper name Ismael. According to Max Wickett, Ismael is just a "Persian warrior" (447). The other significant proper name is "Artaxerxes", who again is a "Persian warrior" (439) for Max. This is a gross injustice to both Tasso and the Persians. Artaxerxes is the proper name of a number of ancient Persian kings, while Ismael was the founder of the Safavid dynasty. By mentioning an ancient and an early modern Persian king fighting together against the crusaders, Tasso is playing the same trick that Gower did by naming Darius as the Sultan of Persia, thereby projecting the Islamic identity of Persia onto ancient Persia. The question, at this point, that one might ask is: How do we know that 'Ismael' in the above stanza is the same as Shah Ismail Safavi? This becomes clear when we read the lines following Ismael's name. 
The details of how he lost control of his horse and how the horse trampled his own rank and file bears a marked resemblance to the accounts of the Battle of Chaldiran fought between him and the Ottoman ruler Selim I. These accounts of the battle mention that Ismail's left arm was wounded. ${ }^{17}$ Tasso has, however, modified the story by suggesting that the horse went out of control because Ismail's left hand was cut off and so his control of the reins was lost. On the other hand, the original accounts of the battle attribute this to the noise of the canons used by the Ottomans against the Persian cavalry. ${ }^{18}$

\section{Conclusion}

In conclusion, all the texts discussed in this paper paint Persia in very different colours when compared to the Persia that is seen as a counterpoint to the Ottomans. This verifies the fact that the Persian identity in early modern England was unstable and fluid. Sometimes Persia is condemned as a country ruled by tyrants, and at other times it is admired as a state ruled by noble and tolerant kings such as Darius and Cyrus. Similarly, in the case of contemporary Persia, great hope is pinned on Safavid Persian kings as the Saviours of Europe and Christianity by opening up a front to the east of the Ottomans, while in some other instances, the same Persians become the worst enemies of Christendom. It seems that Persia was a puzzling case for early modern thinkers owing to its long history and the authors had to grapple with the diverse accounts about Persia that existed at that time. In appropriating these multiple narratives about Persia, they came up with images of Persia that remain contradictory and complicated.

\footnotetext{
${ }^{17}$ See for example, Hasan Celal Guzel, C. O., Osman Karatay (2002) The Turks: Ottomans, Ankara, Yeni Türkiye.

${ }^{18}$ One instance of information about this battle is found in Geuffroy, A. (1542)The order of the greate Turckes courte, of hys menne of warre, and of all hys conquestes, with the summe of Mahumetes doctryne. Translated out of Frenche. 1524 [sic], London, Ricardus Grafton. Narrating the story of the war between Ismail and Selim, the author says: "And as ye forsaid Sophy was come vnto him with a great nou bre of horsses armed and barbed euen vnto Assyrie, he was scatered and dyscomfyted with the artillary of the Turkes, with which the horses of yt Persians had not bene accustomed." pp. Cxxxvii-Cxxxviii.
} 


\section{Works Cited}

Akbari, Suzanne Conklin. Idols in the East: European Representations of Islam and the Orient, 1100-1450. Cornell UP, 2009. Print.

Beckett, Katharine Scarfe. Anglo-Saxon Perceptions of the Islamic World. Cambridge UP, 2003. Print.

Brand, Charles Peter. Torquato Tasso: A Study of the Poet and of His Contribution to English Literature. Cambridge UP, 1965. Print.

Brotton, Jerry. "St George Bbetween East and West." Re-Orienting the Renaissance: Cultural Exchanges with the East, edited by Gerald MacLean, Palgrave Macmillan, 2005. Print.

Burton, Jonathan. Traffic and Turning: Islam and English Drama, 1579-1624.

Delaware UP, 2005. Print.

Chew, Samuel. The Crescent and the Rose: Islam and England during the Renaissance. Oxford UP, 1937. Print.

Classen, Alberecht. "Die Heidin: A Late-Medieval Experiment in Cultural Rapproachment between Christians and Saracens.” Medieval Encounters 11 (2005): 50-70. Print.

Comfort, William. Wistar. “The Saracens in Italian Epic Poetry.” PMLA 59 (1944): 882-910. Print.

Donnelly, John. "The Moslem Enemy in the Renaissance Epic: Ariosto, Tasso, and Camoens.” Yale Italian Studies 1 (1977): 162-170. Print.

Ellis, George. Specimens of Early English Metrical Romances Chiefly Written during the Early Part of the Fourteenth Century..., Longman, Hurst, Rees, and Orme, 1805. Print.

Ewoldt, Amanda M. Conversion and Crusade: The Image of the Saracens in Middle English Romance. 2018. University of Louisiana Lafayette, Unpublished PhD Dissertation. Print.

Gardy, Frank. Representing Righteous Heathens in Late Medieval England. Palgrave Macmillan, 2005. Print.

Geuffroy, Antoine, translator. The Order of the Greate Turckes Courte, of Hys Menne of Warre, and of all Hys Conquestes, with the Summe of Mahumetes Doctryne. 1524 [sic]. Ricardus Grafton, 1542. Print.

Gower, John. This Book is Intituled Confessio Amantis, that is to Saye in Englysshe the Confessyon of the Louer Maad and Compyled . William Caxton, 1483. Print.

Gualterotti, Raffaello. Della Descrizione Del Regale Apparato Fatto Nella Nobile Citta di Firenze per la Venuta, e per le nozze della serenissima madama Christina di Loreno moglie del Serenissimo don Ferdinando Medici terzo gran duca di Toscana. 
Antonio Padovani, 1589. Print.

Guzel, Hasan Celâl, Cem Ougs, and Osman Karatay, editors. The Turks: Ottoman. Yeni Türkiye, 2002. Print.

Hankins, James. "Renaissance Crusaders: Humanist Crusade Literature in the Age of Mehmed II.” Dumbarton Oaks Papers 49 (1995): 111-207. Print.

Hutchings, Mark. “The 'Turk Phenomenon' and the Repertory of the Late Elizabethan Playhouse." Early Modern Literary Studies, The 'Turk Phenomenon' and the Repertory of the Late Elizabethan Playhouse.” Early Modern Literary Studies 10.16 (2007): 1-39. Print.

Hutchings, Mark. Turks, Repertories, and the Early Modern English Stage. Palgrave Macmillan, 2017. Print.

Johnson, Richard. The Renowned History of the Seven Champions of Christendom:... . London, 1596. Print.

Kathleen M Lea, and T. M. Gang, editors. Godfrey of Bulloigne:The Fairfax Translation of Tasso's Gerusalemme Liberata. Clarendon Press, 1981. Print.

Krey, August. Charles, editor. The First Crusade:The Account of Eyewitnesses and Participants. Princeton UP, 1921. Print.

Lee, Sidney. Ed. The Boke of Duke Huon of Burdeux, Early English Texts Society. 1987. Print.

Liebler, Naomi Conn, editor. Early Modern Prose Fiction: The Cultural Politics of Reading. Routledge, 2007. Print.

Margolies, David. Novel and Society in Elizabethan England. Routledge, 1985. Print.

Matar, Nabil. Turks, Moors and Englishmen in the Age of Discovery. Columbia UP, 1999. Print.

Munday, Anthony. Zelauto. The Fountaine of Fame Erected in an Orcharde of Amorous Aduentures .... L London: 1580. Print.

Murray, Alan. "Coroscane: Homeland of the Saracens in the Chansons de Geste and the Historiography of the Crusades." Aspects de l'épopée romane: Mentalité -idéologies - intertextualités, edited by Hans van Dijk and Willem Noomen, Forsten 1995:177-84. Print.

Parr, Anthony, editor. Three Renaissance Travel Plays. Manchester UP, 1995. Print.

Peters, Edward. Ed. The First Crusade: The Chronicle of Fulcher of Charters and Other Source Materials. Pennsylvania UP, 1988. Print.

Reiner, Emily L. The Ambiguous Greek in Old French and Middle English Literature. 2008. University of Toronto, PhD Dissertation. Print.

Robinson, Benedict S. Islam and Early Modern English Literature: The Politics of Ro 
mance from Spenser to Milton. Palgrave Macmillan, 2007. Print.

Rouse, Charles A. "Was Heywood a Servant of the Earl of Southampton?" PMLA 45.3 (1930): 787-790. Print.

Rumble, Thomas. C., editor. The Breton Lays in Middle English. Wayne State UP, 1965. Print.

Salter, David. "Elizabethan Romance.” Literature Compass 1 (2003): 1-13. Print.

Soykut, Mustafa. Image of the "Turk" in Italy: A History of the "Other" in Early Modern Europe: 1453-1683. Klaus Schwarz, 2001. Print.

Speed, Diane. “The Saracens of King Horn.” Speculum 65.3 (1990): 564-595. Print.

Sweetenham, Carol. Ed. Robert the Monk's History of the First Crusade. Ashgate, 2005. Print.

Sweetenham, Carol, and Linda M Paterson. Ed. The Canso d'Antioca: An Occitan Epic Chronicle of the First Crusade. Ashgate, 2003. Print.

Tasso, Torquato. The Liberation of Jerusalem. Oxford UP, 2009. Print.

Uri, SP. “Some Remarks on Partonopeus de Blois.” Neophilologus 37.1 (1953): 83-98. Print.

Vitkus, Daniel. Ed. Three Turk Plays from Early Modern England. Columbia UP, 2000. Print.

Vitkus, Daniel. Turning Turk: English Theatre and the Multicultural Mediterranean, 1 570-1630. Palgrave Macmillan, 2003. Print.

Vitto, Cindy. “The Virtuous Pagan in Middle English Literature.” The American Philosophical Society 79.5 (1989): 1-100. Print.

Zimmerman, Susan. Erotic Politics: Desire on the Renaissance Stage. Routledge, 1992. Print. 